\title{
Potensi Rhizobakteri Sebagai Pelarut Fosfat
}

\author{
S. K. Sugianto, M. Shovitri dan A. Hidayat \\ Departemen Biologi, Fakultas Ilmu Alam, Institut Teknologi Sepuluh Nopember (ITS) Surabaya \\ e-mail: maya@bio.its.ac.id
}

\begin{abstract}
Abstrak-Fosfat merupakan unsur kedua yang penting setelah nitrogen. Ketersediaan fosfat anorganik dalam tanah rendah, karena berikatan dengan $\mathrm{Fe}$, Al dan Ca membentuk senyawa organik, sehingga fosfat tidak dapat diserap oleh tanaman. Rhizobakteria merupakan bakteri yang hidup di daerah rhizosfer tanah. Beberapa anggota rhizobakteria memiliki kemampuan untuk melarutkan fosfat. Tujuan dari penelitian ini adalah untuk mendapatkan bakteri rhizosfer yang mampu melarutkan fosfat dengan menggunakan metode deteksi kualitatif. Pada penelitian ini didapatkan isolat murni yang telah dipurifikasi dari hasil isolasi tanah rhizosfer. Terdapat lima isolat yang mampu hidup bersinergis dan isolat P1, P2, P8 dan P9 berpotensi sebagai pelarut fosfat.
\end{abstract}

Kata Kunci-Asam Organik, Fosfat, Rhizobakteria, Sinergi.

\section{PENDAHULUAN}

$\mathrm{F}^{\mathrm{o}}$ OSFAT adalah nutrisi tanaman terpenting kedua setelah nitrogen. Fosfat tersedia di alam dalam bentuk organik dan anorganik. Ketersediaan P rendah dalam tanah karena berikatan dengan besi, aluminium dan kalsium sebagai fosfat yang tidak larut. Karena kekurangan fosfat adalah faktor kimia terpenting yang membatasi pertumbuhan tanaman, pupuk fosfat kimia banyak digunakan untuk mencapainya hasil optimal. Bentuk larut dari pupuk fosfat yang digunakan dengan mudah diendapkan sebagai bentuk yang tidak larut [1].

Bakteri pelarut fosfat merupakan bakteri tanah yang dapat melarutkan fosfat sehingga dapat diserap oleh tanaman. Selain meningkatkan fosfat dalam tanah juga dapat berperan pada metabolisme vitamin D memperbaiki pertumbuhan akar tanaman dan meningkatkan serapan hara [2]. Fosfat secara biologis berfungsi sebagai elemen struktural asam nukleat dan fosfolipid, sedangkan dalam metabolisme untuk menghasilkan energi dan dalam aktivasi zat antara metabolik sebagai komponen dalam kaskade transduksi sinyal, serta regulasi enzim [3].

Bakteri pelarut fosfat adalah bakteri yang mampu menghasilkan asam-asam organik dan berfungsi untuk mengelat kation ( $\mathrm{Al}, \mathrm{Fe}, \mathrm{Ca}$ ) melalui gugus hidroksil dan karboksilnya yang terikat pada fosfat, kemudian diubah menjadi bentuk fosfat terlarut. Anion karboksilat yang diproduksi oleh bakteri pelarut fosfat (BPF) memiliki afinitas tinggi terhadap kalsium dalam melarutkan fosfat. Hasil pelepasan kalium fosfat (Ca-P) pada tanah basa dan aluminium fosfat (Al-P) atau besi fosfat (Fe-P) pada tanah asam dihasilkan dari efek gabungan penurunan $\mathrm{pH}$ dan sintesis asam karboksilat, namun pelepasan proton tidak dapat menjadi mekanisme tunggal [4].

Rhizobakteria merupakan kelompok bakteri tanah yang berkoloni di daerah rhizosfer (perakaran tanaman) dan mampu mendukung pertumbuhan tanaman, hal tersebut disebabkan pada daerah rhizosfer banyak mengandung nutrisi yang merupakan berbagai jenis eksudat dari tanaman, seperti asam amino, gula, menyediakan sumber energi yang kaya dan nutrisi bagi bakteri. Populasi BPF di daerah rhizosfer mencapai 10-100 kali lebih banyak dibandingkan daerah non-rhizosfer karena rhizosfer mengekskresikan bahan organik yang dapat mencukupi dan merangsang pertumbuhan bakteri [5][6].

Sinergisme antarbakteri dapat memberikan keuntungan untuk kedua populasi, walaupun dua populasi yang sinergis mendapat manfaat dari hasil interaksinya, akan tetapi mereka mampu hidup tanpa bergantung satu sama lain [7]. Penggunaan dua atau lebih bakteri atau disebut konsorsium lebih efektif penggunaannya dalam mendegradasi senyawa kimia dibandingkan dengan isolat tunggal [8]. Keuntungan timbal balik pada suatu konsorsium sangat penting bagi banyak interaksi organisme. Interaksi ini dapat didasarkan pada transfer material yang berkaitan dengan energetika, komunikasi sel ke sel atau perlindungan fisik [9].

Tujuan dari penelitian ini adalah untuk mendapatkan bakteri rhizosfer yang mampu melarutkan fosfat dan mampu hidup bersinergi.

\section{METODOLOGI}

\section{A. Waktu dan Tempat Penelitian}

Penelitian dilakukan sejak bulan Maret sampai dengan Juli 2018. Tempat penelitian di laboratorium Mikrobiologi dan Bioteknologi departemen Biologi Institut Teknologi Sepuluh Nopember Surabaya.

\section{B. Isolasi Bakteri Rhizosfer Tebu}

Sebanyak 1 gram tanah yang dimasukkan ke dalam erlenmeyer, kemudian ditambahkan akuades steril sampai 10 $\mathrm{mL}$ dan dihomogenkan. Selanjutnya larutan tersebut disebut larutan stok. Sebanyak $1 \mathrm{~mL}$ dari larutan stok dimasukkan dalam tabung reaksi berisi $9 \mathrm{~mL}$ akuades steril, kemudian dikocok hingga homogen dan $1 \mathrm{~mL}$ dipindahkan ke tabung berikutnya, begitu seterusnya hingga terjadi seri pengenceran $10^{-1}-10^{-10}$. Sebanyak $0,1 \mathrm{~mL}$ larutan dari seri pengenceran $10^{-3}, 10^{-4}, 10^{-5}, 10^{-6}$ dan $10^{-7}$ dimasukkan ke dalam medium selektif Pikovskaya, kemudian di ratakan menggunakan spreader. Selanjutnya diinkubasi selama 4 hari pada suhu ruang. Koloni dari cawan petri yang memiliki zona bening yang paling besar diantara yang lainnya dipilih dan dipurifikasi dalam media Nutrient Agar dengan metode gores enam belas.

\section{Uji Potensi Melarutkan Fosfat Secara Kualitatif}

Isolat murni diambil satu ose, kemudian diinokulasikan pada medium Nutrient Broth (10 gr petone; 5 gr sodium chloride; 10 gr beef extract; dilarutkan dalam 1 liter $\mathrm{H}_{2} \mathrm{O}$, $\mathrm{pH}=7$ ) lalu dinkubasi selama 24 jam. Selanjutnya, kertas cakram steril dicelupkan ke dalam kultur tersebut dan 
diletakkan di atas medium Pikovskaya padat $\left(5 \mathrm{~g} \mathrm{Ca}_{3}\left(\mathrm{PO}_{4}\right)_{2}\right.$; 10 g glukosa; $0,2 \mathrm{~g} \mathrm{NaCl} ; 0,2 \mathrm{~g} \mathrm{KCl} ; 0,1 \mathrm{~g} \mathrm{MgSO}_{4} .7 \mathrm{H}_{2} \mathrm{O}$; $0,5 \mathrm{~g} \mathrm{NH}_{4} \mathrm{SO}_{4} ; 0,5 \mathrm{~g}$ yeast extract; $0,0001 \mathrm{~g} \mathrm{MnSO}_{4}$ dan $0,0001 \mathrm{~g} \mathrm{FeSO}_{4}$ dilarutkan dalam 1 liter $\mathrm{H}_{2} \mathrm{O}, \mathrm{pH}=7$ ) menggunakan kertas cakram dan dilakukan seperti pada Gambar 1. Hal tersebut dilakukan sebanyak tiga kali pengulangan. Kemudian diinkubasi selama 4 hari pada suhu ruang. Bakteri yang mampu melarutkan fosfat ditandai dengan membentuk zona bening disekitar isolat. Nilai kelarutan fosfat dihitung menggunakan perhitungan menurut [10]:

Phosphate Solubilization Index :

\section{Diameter Koloni+Diameter Zona Bening Diameter Koloni}

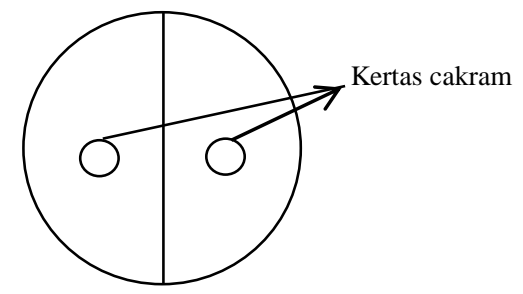

Gambar 1. Uji bakteri Pelarut Fosfat Menggunakan Metode Cakram.

\section{Uji Sinergisme Antarisolat}

Satu ose kultur murni isolat A diinokulasikan di tengah medium Nutrient Agar (NA) plate secara vertikal. Kemudian isolat lainnya diinokulasikan secara horizontal dengan melewati goresan isolat pertama, seperti pada Gambar 2 dan diinkubasi selama 24 jam pada suhu ruang. Selanjutnya diamati pertumbuhannya antarisolat. Hasil positif ditunjukkan dengan tidak terbentukknya zona hambat antarisolat. Hasil positif mengindikasikan bahwa isolat tersebut berpotensi sebagai konsorsium.

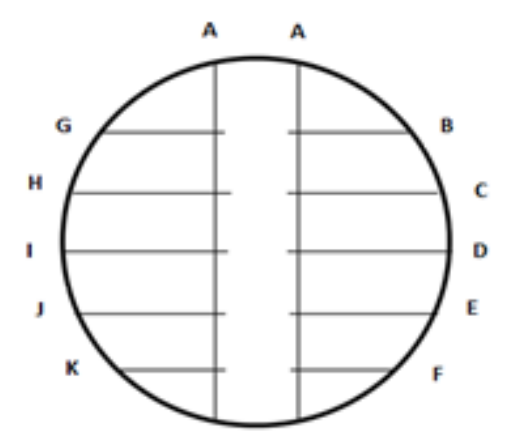

Gambar 2. Uji Sinergisme dengan Metode Streak Line. Huruf A-G menunjukkan isolat yang dikombinasikan untuk uji sinergisme.

\section{HASIL DAN PEMBAHASAN}

\section{A. Isolasi Bakteri Rhizosfer}

Isolasi bakteri rhizosfer dari lahan tebu milik PTPN X menghasilkan dua puluh tujuh isolat yang yang memiliki kemampuan melarutkan fosfat yang diskrining menggunakan medium selektif Pikovskaya (Gambar 3). Penggunaan medium selektif untuk menyeleksi secara langsung bakteri target. Hal tersebut karena kelimpahan bakteri tanah sangat tinggi, jika dikulturkan pada medium pengaya, seperti Nutrient Agar (NA) dan Potato Dextrose Agar (PDA).
Menurut [11], melaporkan bahwa kelimpahan bakteri tanah tersebut bisa mencapai $3.0 \times 10^{6}-5.0 \times 10^{8} \mathrm{CFU}$ per gram tanah pada medium NA. Menurut [6], melaporkan bahwa jumlah bakteri pelarut fosfat di daerah rhizosfer rata-rata $10^{6}$ - $10^{7} \mathrm{sel} / \mathrm{gr}$ tanah, sedangkan di luar daerah rhizosfer $10^{5}$ sel/g tanah. Hal ini karena daerah rhizosfer merupakan daerah yang kaya akan komponen karbon (C) yang dapat digunakan sebagai sumber energi untuk pertumbuhan mikroba tanah dan salah satunya adalah bakteri pelarut fosfat.

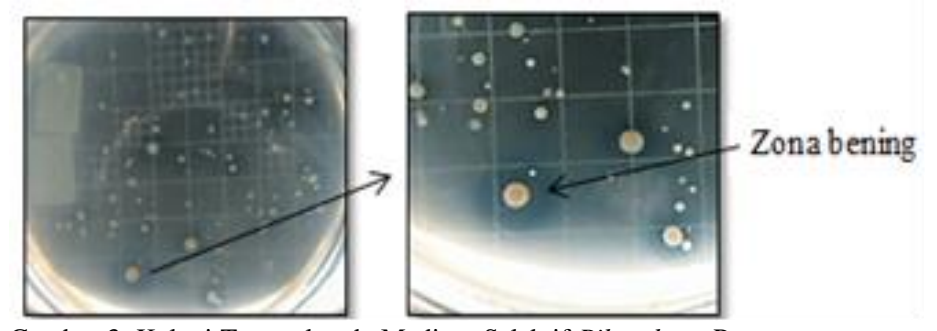

Gambar 3. Koloni Tunggal pada Medium Selektif Pikovskaya Pengenceran $10^{5}$ Setelah Masa Inkubasi 4 Hari.

Ada empat belas koloni tunggal pada medium Pikovskaya yg membentuk zona bening (Gambar 3). Zona bening yang terbentuk menunjukkan bahwa bakteri tersebut mampu melarutkan fosfat [12]. Selanjutnya, koloni tunggal tersebut dipurifikasi pada medium Nutrient Agar (NA) menggunakan metode enam belas gores (Gambar 4).

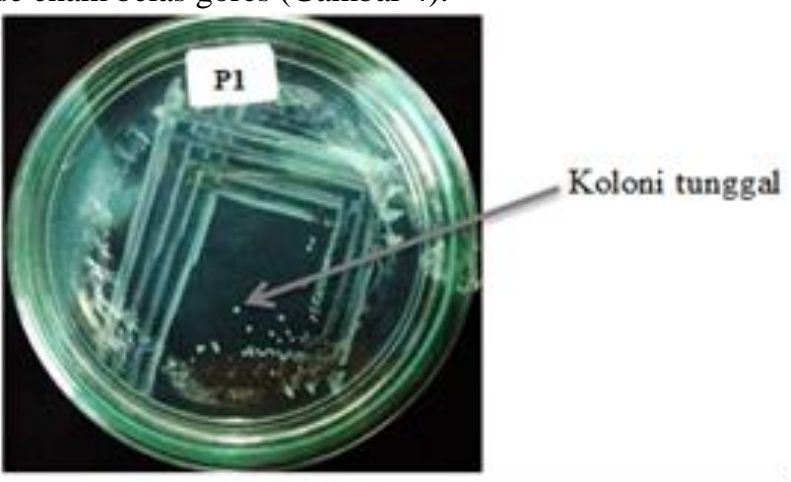

Gambar 4. Purifikasi Isolat P1 Menggunakan Metode Enam Belas Gores pada Medium NA dengan Masa Inkubasi 24 Jam.

Berdasarkan pertumbuhannya, dari empat belas isolat bakteri pelarut fosfat hanya empat isolat yang mampu tumbuh dengan cepat dalam waktu 24 jam. Sedangkan sepuluh isolat lainnya membutuhkan waktu yang lebih lama untuk tumbuh, yakni lebih dari 48 jam (Tabel 1).

Lambatnya pertumbuhan isolat bakteri, diduga karena bakteri tersebut kurang optimal dalam memanfaatkan sumber karbon yang terdapat dalam medium NA. Sebaliknya, pertumbuhan bakteri yang cepat diduga karena bakteri secara optimal memanfaatkan sumber karbon pada medium NA. Menurut [13], melaporkan bahwa tidak semua bakteri tanah, khususnya bakteri dari filum Proteobacteria yang berasosiasi dengan rhizosfer tanaman memiliki respon yang stabil terhadap sumber karbon. Pemilihan bakteri dengan pertumbuhan yang cepat dibutuhkan untuk diaplikasikan sebagai agen biofertilizer. Hal tersebut dikarenakan bakteri akan lebih cepat mencapai fase eksponensial, dimana pada fase ini sel bakteri secara biokimia dan fisiologis telah siap untuk diberi perlakuan dan digunakan sebagai kultur starter [9]. 
Tabel 1.

Pertumbuhan Bakteri pada Medium Nutrient Agar (NA)

\begin{tabular}{|c|c|c|c|c|c|}
\hline \multirow{2}{*}{ No. } & \multirow{2}{*}{ Isolat } & \multirow{2}{*}{ Potensi Bakteri } & \multicolumn{2}{|c|}{ Waktu Tumbuh } & \multirow{2}{*}{ Keterangan } \\
\cline { 5 - 6 } & & & 24 jam & $\geq 48$ jam & \\
\hline 1. & P1 & Pelarut Fosfat & $\sqrt{ }$ & - & $\sqrt{ } \sqrt{ }$ \\
\hline 2. & P2 & Pelarut Fosfat & $\sqrt{ }$ & - & $\sqrt{ }$ \\
\hline 3. & P3 & Pelarut Fosfat & - & $\sqrt{ }$ & $\mathrm{x}$ \\
\hline 4. & P4 & Pelarut Fosfat & - & - & $\mathrm{x}$ \\
\hline 5. & P5 & Pelarut Fosfat & $\sqrt{ }$ & & $\sqrt{ }$ \\
\hline 6. & P6 & Pelarut Fosfat & - & - & $\mathrm{x}$ \\
\hline 7. & P7 & Pelarut Fosfat & - & $\sqrt{ }$ & $\mathrm{x}$ \\
\hline 8. & P8 & Pelarut Fosfat & $\sqrt{ }$ & - & $\sqrt{ }$ \\
\hline 9. & P9 & Pelarut Fosfat & $\sqrt{ }$ & - & $\sqrt{ }$ \\
\hline 10. & P10 & Pelarut Fosfat & - & $\sqrt{ }$ & $\mathrm{x}$ \\
\hline 11. & P11 & Pelarut Fosfat & - & $\sqrt{ }$ & $\mathrm{x}$ \\
\hline 12. & P12 & Pelarut Fosfat & - & $\sqrt{ }$ & $\mathrm{x}$ \\
\hline 13. & P13 & Pelarut Fosfat & - & $\sqrt{ }$ & $\mathrm{x}$ \\
\hline 14. & P14 & Pelarut Fosfat & - & $\sqrt{ }$ & $\mathrm{x}$ \\
\hline
\end{tabular}

Keterangan:

$$
\begin{array}{cll}
\sqrt{ } & : & \text { isolat mampu tumbuh; } \\
- & : & \text { isolat tidak mampu tumbuh; } \\
\sqrt{ } \sqrt{ } & : & \text { isolat dipilih untuk perlakuan selanjutnya; } \\
\mathrm{x} & : & \text { isolat tidak dipilih untuk perlakuan selanjutnya. }
\end{array}
$$

\section{B. Uji Pelarutan Fosfat Secara Kualitatif}

Dari lima isolat yang digunakan dalam penelitian ini terdapat empat isolat yang positif stabil melarutkan fosfat dalam medium selektif Pikovskaya, yakni isolat P1, P2, P8 dan P9. Kemampuan isolat P1, P2, P8 dan P9 dalam melarutkan fosfat ditunjukkan dengan pembentukan zona bening disekitar koloni (Gambar 5). Berdasarkan diameter zona bening yang terbentuk dapat dilihat pada Tabel 3.
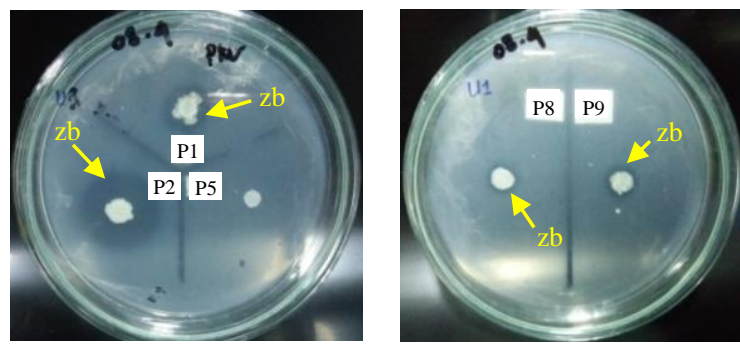

Gambar 4. Kemampuan Isolat P1, P2, P8 dan P9 Melarutkan Fosfat dengan diterbentuknya Zona Bening (zb).

Zona bening yang terbentuk di sekeliling koloni merupakan indikasi bahwa isolat tersebut mampu melarutkan fosfat kompleks. Zona bening pada medium Pikovskaya agar dapat terbentuk akibat pelarutan suspensi trikalsium fosfat $\left(\mathrm{Ca}_{3}\left[\mathrm{PO}_{4}\right]_{2}\right)$. Pembentukan zona bening pada medium Pikovskaya mengindikasikan bahwa mikroorganisme tersebut dapat melarutkan fosfat [12].

Tabel 3.

Lebar Zona Bening dan Phosphate Solubilization Index Setelah 4 Hari Masa Inkubasi

\begin{tabular}{|c|c|c|c|}
\hline \multirow{2}{*}{ Isolat } & \multicolumn{2}{|c|}{ Diameter (mm) } & \multirow{2}{*}{ PSI } \\
\cline { 2 - 4 } & Koloni & Zona bening & \\
\hline P1 & 6 & 6 & 200 \\
\hline P2 & 7 & 14 & 300 \\
\hline P5 & - & - & - \\
\hline P8 & 6 & 7 & 216,7 \\
\hline P9 & 8 & 7 & 187,5 \\
\hline
\end{tabular}

PSI: Phosphate Solubilization Index
Pada Tabel 3 terlihat bahwa zona bening terbesar dimiliki oleh isolat P2 dan zona bening terkecil dimiliki oleh isolat $\mathrm{P} 1$. Sedangkan berdasarkan nilai PSI, isolat P2 memiliki nilai PSI tertinggi dan yang terendah dimiliki oleh isolat P9. Besarnya lebar zona bening tidak selalu mengindikasikan banyaknya jumlah konsentrasi fosfat yang terlarut [1]. Kemampuan pelarutan fosfat bakteri dapat dilihat dari nilai indeks pelarutan fosfatnya [14], sehingga berdasarkan nilai PSI, isolat P2 memiliki potensi pelarutan fosfat lebih tinggi dibanding isolat uji lainnya.

Bakteri pelarut fosfat adalah bakteri mampu yang menghasilkan asam-asam organik yang berfungsi untuk mengelat kation ( $\mathrm{Al}, \mathrm{Fe}, \mathrm{Ca}$ ) melalui gugus hidroksil dan karboksilnya yang terikat pada fosfat, kemudian diubah menjadi bentuk fosfat terlarut. Kemudian fosfat dalam bentuk terlarut akan diabsorsi oleh tanaman melalui gradien potensial air pada akar [4]. Mikroorganisme mampu menurunkan $\mathrm{pH}$ di dalam medium tumbuhnya melalui produksi asam organik atau proton-proton yang menyebabkan pelarutan kompleks mineral-fosfat melalui pertukaran anion $\mathrm{PO}_{4}{ }^{2-}$ dengan anion asam atau pengkhelatan ion mineral yang mengikat fosfat [15].

Isolat yang positif stabil melarutkan fosfat, selanjutnya diidentifikasi secara makroskopis, mikroskopis dan karakter biokimianya. Adapun karakter tersebut tertera dalam Tabel

\begin{tabular}{|c|c|c|c|c|c|}
\hline \multicolumn{2}{|c|}{ Parameter } & P1 & P2 & P8 & P9 \\
\hline \multirow{5}{*}{ Makroskopis } & $\begin{array}{l}\text { Warna } \\
\text { Koloni }\end{array}$ & Putih & $\begin{array}{c}\text { Putih } \\
\text { Kekuningan }\end{array}$ & Putih & Putih \\
\hline & \begin{tabular}{|l|} 
Ukuran \\
Koloni
\end{tabular} & Small & Small & Small & Small \\
\hline & Margin & Entire & Entire & Entire & Entire \\
\hline & Elevasi & Convex & Convex & Convex & Convex \\
\hline & \begin{tabular}{|l|} 
Bentuk \\
Koloni
\end{tabular} & Circular & Circular & Circular & Circular \\
\hline Mikroskopis & $\begin{array}{l}\text { Bentuk } \\
\text { Bakteri }\end{array}$ & Rod & Rod & Rod & Rod \\
\hline \multirow{7}{*}{$\begin{array}{l}\text { Karakter } \\
\text { Biokimia }\end{array}$} & $\begin{array}{l}\text { Bakteri } \\
\text { Gram }\end{array}$ & $\begin{array}{l}\text { Gram } \\
\text { Positif }\end{array}$ & $\begin{array}{c}\text { Gram } \\
\text { Negatif }\end{array}$ & $\begin{array}{c}\text { Gram } \\
\text { Negatif }\end{array}$ & $\begin{array}{c}\text { Gram } \\
\text { Negatif }\end{array}$ \\
\hline & $\begin{array}{l}\text { Pewarnaan } \\
\text { Endospora }\end{array}$ & Positif & Negatif & Negatif & Negatif \\
\hline & Motilitas & Positif & Positif & Positif & Positif \\
\hline & $\begin{array}{l}\text { Kebutuhan } \\
\text { Oksigen }\end{array}$ & $\begin{array}{l}\text { Anaerob } \\
\text { fakultatif }\end{array}$ & $\begin{array}{l}\text { Anaerob } \\
\text { fakultatif }\end{array}$ & $\begin{array}{l}\text { Anaerob } \\
\text { fakultatif }\end{array}$ & $\begin{array}{l}\text { Anaerob } \\
\text { fakultatif }\end{array}$ \\
\hline & \begin{tabular}{|l|} 
Enzim \\
Katalase
\end{tabular} & $\sqrt{ } \sqrt{ }$ & $\sqrt{ } \sqrt{ } \sqrt{ }$ & $\sqrt{ } \sqrt{ }$ & $\sqrt{ } \sqrt{ }$ \\
\hline & Uji Oksidase & + & + & + & + \\
\hline & $\begin{array}{l}\text { Fermentasi } \\
\text { Glukosa }\end{array}$ & + & + & + & + \\
\hline
\end{tabular}
3.

Tabel 3.

Identifikasi Makroskopis, Mikroskopis dan Karakter Biokimia Isolat

Sedikitnya karakter biokimia yang diuji (Tabel 3), menyebabkan isolat belum dapat diidentifikasi genus dan spesiesnya. Ada banyak karakter biokimia lain yang harus diketahui seperti uji fermentasi jenis-jenis gula, produksi $\mathrm{H}_{2} \mathrm{~S}$, penghasil Indole, uji MR-VP, uji pemanfaatan sitrat dan lain-lain [16]. Ada pula cara identifikasi yang cepat dilakukan yaitu dengan identifikasi molekuler menggunakan gen $16 \mathrm{~S}$ rRNA. Gen 16S rRNA terdiri dari urutan nukleotida dengan daerah variabel genus atau spesies yang spesifik dan bersifat tetap (conserved gene) [17].

\section{Sinergisme Antarisolat}

Pada pertumbuhan isolat P1, P2, P5, P8 dan P9 di medium Nutrient Agar yang bersinggungan, menunjukkan 
tidak adanya zona hambat yang terbentuk. Sinergitas yang terbentuk antara kelima isolat tersebut (Tabel 4), diduga karena adanya interaksi saling menguntungkan secara timbal balik. Interaksi tersebut dapat didasarkan pada transfer material yang berkaitan dengan energetika, komunikasi sel ke sel atau perlindungan fisik [9].

Tabel 4.

Uji Sinergisme Antarisolat

\begin{tabular}{|c|c|c|c|c|c|}
\hline Isolat & P1 & P2 & P5 & P8 & P9 \\
\hline P1 & & + & + & + & + \\
\hline P2 & + & & + & + & + \\
\hline P5 & + & + & & + & + \\
\hline P8 & + & + & + & & + \\
\hline P9 & + & + & + & + & \\
\hline
\end{tabular}

Sinergitas antara isolat tersebut (Tabel 4), menunjukkan bahwa tidak terdapat aktivitas antagonis antara satu dengan yang lainnya dari lingkungan yang sama melalui produksi agen antimikroba potensial. Selain itu, pertumbuhan sinergis bakteri bergantung pada kompleksitas struktural dari sumber karbon dilingkungan yang sama. Pertumbuhan sinergis tersebut dapat terjadi ketika beberapa spesies menghasilkan enzim komplementer dan mengambil bagian dalam umpan silang metabolit. Umpan silang metabolit memungkinkan bakteri untuk memanfaatkan substrat kompleks dengan cara kooperatif [18].

Selama akhir masa pertumbuhan, biasanya beberapa spesies dalam suatu konsorsium dapat menghasilkan metabolit yang beracun bagi diri mereka sendiri tetapi digunakan oleh yang lainnya. Sinergitas dalam suatu konsorsium dapat terjadi karena beberapa bakteri mungkin menghasilkan enzim secara lebih efektif, sementara yang lain dapat memproduksi eksudat stimulasi atau molekul yang mengoordinasikan interaksi antarbakteri [18].

\section{KESIMPULAN}

Pada penelitian ini didapatkan isolat murni hasil isolasi dari tanah rhizosfer. Isolat murni P1, P2, P8 dan P9 mampu melarutkan fosfat secara kualitatif yang ditunjukkan dengan pembentukan zona bening pada medium Pikovskaya. Nilai PSI tertinggi dimiliki oleh isolat P2 yang berpotensi tinggi dalam melarutkan fosfat dibanding isolat lainnya. Isolat P1, P2, P5, P8 dan P9 mampu hidup bersinergi.

\section{DAFTAR PUSTAKA}

M. Alam , S., Khalil, S., Ayub, N. and Rashid, "In vitro Solubilization of Inorganic Phosphate by Phosphate Solubilizing Microorganisms (PSM) from Maize Rhizosphere," Int. J. Agric. Biol., vol. 4, no. 4, 2002. sp. Terhadap Pertumbuhan Tanaman Kedelai (Glycine max L.) pada Tanah Podsolik Merah Kuning," J. Natur Indones., vol. 4, no. 1, pp. 21-25, 2005.

[3] M. Rausch, Christine and Bucher, "Molecular Mechanisms of Phosphate Transport in Plants," Planta, vol. 216, pp. 23-37, 2002.

[4] M. Khan, A. A., Jilani, G, Akhtar, Mohammad S., Saqlan, Syed M., Naqvi, Rashee, "Phosphorus Solubilizing Bacteria: Occurrence, Mechanisms and Their Role in Crop Production," $J$. Agric. Biol. Sci., vol. 1, no. 1, pp. 48-58, 2009.

[5] R. Prayudyaningsih, R., Nursyamsi dan Sari, "Mikroorganisme Tanah Bermanfaat pada Rhizosfer Tanaman Umbi di bawah Tegakan Hutan Rakyat Sulawesi Selatan," in Prosiding Seminar Nasional Masyarakat Biodiversitas Indonesia, 2015, pp. 954 959.

[6] S. dan S. Widawati, "Populasi Bakteri Pelarut Fosfat (BPF) di Cikaniki, Gunung Botol, dan Ciptarasa, serta Kemampuannya Melarutkan P Terikat di Media Pikovskaya Padat," Biodiversitas, vol. 7, no. 2, pp. 109-113, 2006.

[7] F. H. Chapelle, Ground-Water Microbiology and Geochemistry Second Edition. Canada: John Wiley \& Sons, 2001.

[8] E. Asri, A. C. dan Zulaika, "Sinergisme Antarisolat Azotobacter yang Dikonsorsiumkan," J. Sains dan Seni ITS, vol. 5, no. 3, pp. 2337-3520, 2016

[9] and W. C. J. Willey J.M., Sherwood L.M., Prescott, Harley, and Klein's Microbiology Seventh Edition. New York: The McGrawHill Companies, Inc, 2008.

[10] S. Jabin, P.P. N. and Ismail, "Solubilization of Insoluble Potassium by Different Microbial Isolates in vitro Condition," Int. J. Curr. Microbiol. Appl. Sci., vol. 6, no. 10, pp. 3600-3607, 2017.

[11] E. Ogunmwonyi, I. N., Igbinosa, O. E., Aiyegoro, O. A. and Odjadjare, "E. Microbial Analysis of Different Top Soil Samples of Selected Site in Obafemi Awolowo University, Nigeria," Sci. Res. Essay, vol. 3, no. 3, pp. 120-124, 2008.

[12] E. dan S. Atekan, Nuraini, Y., Handayanto, "The Potential of Phosphate Solubilizing Bacteria Isolated From Sugarcane Wastes for Solubilizing Phosphate," J. Degrad. Min. Lands Manag., vol. 1, no. 4, pp. 175-182, 2014.

[13] N. A. Youssef , H. H., Hamza, M. A., Fayez, M., Mourad, E. F. Saleh, M. Y. Sarhan, M. S., Suker, Ragab M., Eltahlawy, A. A., Nemr, R. A., El-Tahan, M., Ruppelc, S. and Hegazi, "PlantBased Culture Media: Efficiently Support Culturing Rhizobacteria and Correctly Mirror Their In-situ Diversity," $J$. Adv. Res., vol. 7, no. 2, pp. 305-316, 2016.

[14] A. E. H. dan H. M. Mohamed, "Molecular Genetic Identification of Yeast Strains Isolated from Egyptian Soils for Solubilization of Inorganic Phosphates and Growth Promotion of Corn Plants," J. Microbiol. Biotechnol., vol. 21, no. 1, pp. 55-61, 2011.

[15] L. J. P. dan P. S. P. P. Gyaneshwar, G. N. Kumar, "Role of Soil Microorganisms in Improving P Nutrition of Plants," Plant Soil, vol. 245, pp. 83-93, 2002.

[16] J. . et. al Holt, Bergey's Manual of Determinative Bacteriology Ninth Edition. Philadelphia: A Wolters Kluw, 1994.

[17] C. C. Jenkins, C., Ling, C. L., Ciesielczuk, Holly L., Lockwood, J., Hopkins, S., McHugh, Timothy D., Gillespie, Stephen H. and Kibbler, "Detection and Identification of Bacteria in Clinical Samples by 16S rRNA Gene Sequencing: Comparison of Two Different Approaches in Clinical Practice," J. Med. Microbiol., vol. 61, pp. 483-488, 2016.

[18] S. Y. Deng, Yi J. and Wang, "Synergistic Growth in Bacteria Depends on Substrate Complexity," J. Microbiol., vol. 54, no. 1, pp. 23-30, 2016. 